\title{
Impact of Salinity on Seed Germination and Early Seedling Growth of Three Sorghum (Sorghum biolor L. Moench) Cultivars
}

\author{
Ahmed M. EI Naim*, Khawla E. Mohammed, Elshiekh A. Ibrahim, Nagla N. Suleiman \\ Department of Crop Science, Faculty of Natural Resources and Environmental Studies, University of Kordofan, Elobeid, Sudan
}

\begin{abstract}
The environmental stress such as, salinity (soil or water) are serious obstacles for field crops especially in the arid and semi-arid tracts of the world. In the Sudan, with the rapid expansion of irrigated agriculture, the question of soil salinity is becoming more and more urgent for naturally salt-affected lands under cultivation and maintaining the productivity of existing irrigated areas. It could be alleviated using irrigation and crop management. However, the former approach is very expensive. The latter is economical as well as efficient and it enables to produce salt tolerant crop varieties. Also other is a need to confirm the presence of genetically based variation for salt tolerance among different varieties of a particular crop at different plant growth stages. In order to investigate salinity stress on sorghum germination indices, an experiment was carried out in Sudan from September 2011 to October 2011 at University of Kordofan, in the Crop Sciences Department Laboratory, to create salinity stress, sodium chloride $(\mathrm{Na} \mathrm{Cl})$ at the levels of 0 (as control), 2, 4, 8 and $16 \mathrm{dS} / \mathrm{m}$ and three sorghum (Sorghum bicolor L. Moench) cultivars (Arfagadamak, Wad Ahmed and Butana) were tested. Seed germination percentage, seedling root dry weight and seedling shoot dry weight were measured. Low level of salinity $(2 \mathrm{dS} / \mathrm{m})$ increased seed germination percentage, while the high levels $(4,8$ and $16 \mathrm{dS} / \mathrm{m})$ inhibited the seed germination significantly. The strongest inhibition of germination occurred at the higher salt concentrations. Growth of young seedlings was also reduced, especially at the higher salt concentrations. Wad Ahmed cultivar was found to be salt tolerant during seedling biomass production. Arfagadamak and Butana cultivars were found to be salt sensitive during seedling biomass production. The study revealed the presence of broad intra specific genetic variation in sorghum varieties for salt stress with respect to their early biomass production.
\end{abstract}

Keywords Sorghum, Seed germination, , Seedling biomass, Salinity, $\mathrm{NaCl}$

\section{Introduction}

Salinity is the accumulation of salt in soil and water. High salt levels can adversely affect plant growth, soil structure, water quality and infrastructure. Salinization of soil is one of the major factors limiting crop production particularly in arid and semi-arid regions of the world (Ahmed, 2009). In the world about 830 million hectares are affected by salt. Sudan had about 4.8 million hectares are salt affected to various degrees (FAO, 2000). Salt stress is known to perturb a multitude of physiological processes (Noreen and Ashraf, 2008). It exerts its undesirable effects through osmotic inhibition and ionic toxicity (Munns et al., 2006). Increased salinity caused a significant reduction in germination percentage, germination rate, and root and shoots length and fresh root and shoots weights (Jamil et al., 2006). In the Sudan, with

* Corresponding author:

naim17amn@yahoo.com (Ahmed M. El Naim)

Published online at http://journal.sapub.org/scit

Copyright (C) 2012 Scientific \& Academic Publishing. All Rights Reserved the rapid expansion of irrigated agriculture, the question of soil salinity is becoming more urgent, not only for putting naturally salt-affected lands under cultivation, but also for maintaining the productivity of existing irrigated areas. The Sudan lies wholly within the tropics, between latitudes $3^{\circ} \mathrm{N}$ and $22^{\circ} \mathrm{N}$. Ecological conditions vary considerably from the desert in the north to the arid and semi-arid savanna areas of central Sudan and to the sub-humid areas of the southern provinces. The soils of northern Sudan are affected to a greater degree by soil salinity, particularly from Khartoum northwards along both banks of the Nile. The area affected by salinity in the Sudan can only be estimated, since few systematic surveys have been made. However, the areas which are potentially irrigable but where salinity is the main limiting factor for its development cover more than 200,000 hectares.

The total area of irrigated land in the Sudan comprises about 1.6 million ha but there are several new irrigation projects under construction. These could increase the total irrigated area to perhaps four million ha. Thus in the near future problems of soil salinity are likely to be encountered 
on a larger scale. This problem is expected to be severe in years to come. Because under the prevailing situation of the country; there is a tendency to introduce and implement large-scale irrigation agriculture so as to increase productivity (Mamo et al., 1996). The area south of Khartoum between the Blue and the White Nile and extending as far south as the northwest boundary of the Gezira Scheme is predominantly saline and/or sodic. Due to salinity problems this area has never been utilized agriculturally in any form except for a short-lived animal fattening scheme, but low productivity of the land was one of the factors that contributed to its failure.

However, because of high-quality irrigation water from the two Niles (Blue and White Nile), good roads which connect the area with Khartoum throughout the year, and availability of health and electric services, the area has recently gained importance for growing high-value crops for local consumption and export. In the absence of efficient ways of irrigation water management, salt-build up is an inevitable problem. To alleviate the problem, we need to look for a solution (Gebre and Georgis, 1988). It can be done either using physical or biological practice (Gupta and Mihas, 1993; Marler and Mickelbart, 1993). Since physical approach (environmental management) is not economically feasible (El-Khashab et al., 1997). Therefore there is a need to concentrate on the crop management or biological approach (Ashraf and McNeilly, 1988, Ashraf et al., 2008; Ashraf, 2009). Nevertheless, to proceed with this approach, affirming the presence of genetically based variation for salt-tolerance in a particular crop is a prerequisite (Verma and Yadava, 1986; Marler and Mickelbart, 1993; Mahmood et al., 2009). This could be done at different crop growth stages such as crop establishment (germination, emergence and seedling growth). There are reasonably adequate information on the effects of salinity on crops germination and emergence (Maas, 1986).However, there is a meagre information on the impacts of salinity on crops biomass production during seedling growth (Katerji et al., 1994).Therefore, this research attempted to investigate the response of three sorghum (Sorghum bicolor, L. Moench) cultivars for salt stress with respect to seedling biomass production. The reason for selecting sorghum for the research are: being a dual crop grown for both grain and forage, native to tropical regions (Azhar and McNeilly, 1987; El Naim et el., 2011), and its resistance to environmental fluctuations and drought (Marambe and Ando, 1995). Moreover, previous reports on salt tolerance of sorghum are relatively few. Seed germination is an important and vulnerable stage in the life cycle of terrestrial angiosperms and determines seedling establishment and plant growth. Despite the importance of seed germination under salt stress (Ungar, 1995), the mechanisms of salt tolerance in seeds is relatively poorly understood, especially when compared with the amount of information currently available about salt tolerance physiology and bio-chemistry in vegetative plants (Garthwaite et al., 2005; Kanai et al.,2007; Keshavarzi, 2011). In vegetative plants, salt stress causes reduced cell turgor and depressed rates of root and leaf elongation (Werner and Finkelstein, 1995; Fricke et al., 2006), suggesting that environmental salinity acts primarily on water uptake. Furthermore, high intracellular concentrations of both $\mathrm{Na}+$ and $\mathrm{Cl}_{2}$ can inhibit the metabolism of dividing and expanding cells (Neumann, 1997), retarding germination and even leading to seed death.

Seed germination is a critical stage in the history of plants and salt tolerance during germination is crucial for the establishment of plants that grow in saline soils. This research was carried out in order to test the effects of different salinity levels on germination and early growth of Sorghum (Sorghum biolor L. Moench).

\section{Materials and Methods}

\subsection{Experiment}

This study was carried out in Sudan from September 2011 to October 2011 at University of Kordofan in the Crop Sciences Department Laboratory. Seeds of three growing sorghum (Sorghum bicolor L. Moench) cultivars were obtained from the Arab- Sudanese Seed Company, Elobeid, Sudan. The specific sorghum cultivars used in the research were Arfagadamak, Wad Ahmed and Butana, designated as $\mathrm{V}_{1}, \mathrm{~V}_{2}$ and $\mathrm{V}_{3}$ respectively. The $\mathrm{NaCl}$ on centrations used were 2, 4, 8 and $16 \mathrm{dS} / \mathrm{m}$, designated as $\mathrm{S}_{0}, \mathrm{~S}_{2}, \mathrm{~S}_{4}, \mathrm{~S}_{8}$ and $\mathrm{S}_{16}$ respectively. These salinity levels were obtained by dissolving 1.12 , $2.10,4.95$ and $9.9 \mathrm{~g} \mathrm{NaCl}$ in one liter distilled water respectively. Distilled water $(0 \mathrm{dS} / \mathrm{m})$ was used as a control. Germination experiment was conducted in a laboratory at room temperature following the procedures used by Mamo et al. (1996). Petri dishes with a diameter of $10 \mathrm{~cm}$ lined with Whatman No.1 filter paper were supplied with $10 \mathrm{ml}$ of each treatment solution and the control. Following this, twelve uniform seeds of each sorghum variety were placed on each petri dish and the petri dishes were arranged in a Randomized Complete Block Design (RCBD) with three replications. Eventually, the petri dishes were covered with a polyethylene sheet to avoid the loss of moisture through evaporation. Treatment application continued every other day and germination count was started after 48 hours of sowing and continued until the 14th day. The seeds were considered to have germinated when their radicle length was more than 3 $\mathrm{mm}$. The final germination percentage (FGP) calculated as the follows:

$$
\begin{gathered}
\mathrm{GP}=\mathrm{Ni} / \mathrm{N} \times 100 \\
\mathrm{Ni}=\begin{array}{c}
\text { number of germinated seed till } \mathrm{i}^{\text {th }} \text { day) } \\
\mathrm{N}=\text { total number of seeds }
\end{array}
\end{gathered}
$$

After the 14 days, seedling shoot and root fresh weights were recorded and finally oven dried at $80^{\circ} \mathrm{C}$ for $48 \mathrm{~h}$ and the seedling shoot and dry weight were measured using sensitive balance.

\subsection{Statistical Analysis}

Data analysis was carried out according to the statistical procedure described by Gomez and Gomez (1984) and the computer package MSTAT-C. Means were separated using 
the Duncan's Multiple Range Test.

\section{Results and Discussion}

The effect of salinity (Na CL concentration) on seed germination percentage is shown in Table 1. low level of salinity $(2 \mathrm{dS} / \mathrm{m})$ increased germination percentage. The seed germination percentage decreased as the level of salinity increased. High levels of salinity inhibit the seed germination significantly. This agree with pervious record of Duan et al. (2007) in Suaeda salsa. The effects of salinity on final seed germination percentage (FGP) are represented in Table 2 . The seed germinate best in non-saline control and salinity $(2 \mathrm{dS} / \mathrm{m})$ treatments and then seed germination percentages decreased as salinity increased. $V_{2}$ cultivar was rapid emergence and had highest final germination percentage

Table 1. The effect of salinity levels on Seed Germination percentage (at 24h) of Sorghum bicolor L. Moench cultivars

\begin{tabular}{ccccc}
\hline Treatments & $\mathrm{V}_{1}$ & $\mathrm{~V}_{2}$ & $\mathrm{~V}_{3}$ & Mean \\
\hline $\mathrm{S}_{0}$ & 75 & 88 & 67 & $76.7^{\mathrm{b}}$ \\
$\mathrm{S}_{2}$ & 78 & 92 & 88 & $86.0^{\mathrm{a}}$ \\
$\mathrm{S}_{4}$ & 52 & 78 & 52 & $60.1^{\mathrm{c}}$ \\
$\mathrm{S}_{8}$ & 50 & 55 & 50 & $51.7^{\mathrm{d}}$ \\
$\mathrm{S}_{16}$ & 41 & 49 & 39 & $43.3^{\mathrm{e}}$ \\
Mean & 59.5 & 72.6 & 59.2 & \\
\hline
\end{tabular}

Shoot dry weight decreased as the salinity level increased (Table 3). This does agree with previous studies conducted in sorghum (Asfaw, 2011) and in other different crops (Mamo et al., 1996, Bayuelo-Jimenez et al., 2002). Increased salinity level caused simultaneous reduction of seedling shoots and roots dry weights in all cultivars (Table 1 and 2). This is in line with previous reports in wheat (Afzal et al., 2005), and sugar beat, cabbage, amaranth and pak-choi (Jamil et al., 2006) and in sorghum (Asfaw, 2011). In general, seedling shoot dry weight was more salt affected than seedling Root dry weight.

Table 2. The effect of salinity levels on final seed germination percentage (FGP) of Sorghum bicolor L. Moench cultivars

\begin{tabular}{ccccc}
\hline Treatments & $\mathrm{V}_{1}$ & $\mathrm{~V}_{2}$ & $\mathrm{~V}_{3}$ & Mean \\
\hline $\mathrm{S}_{0}$ & 92 & 94 & 94 & $93.3 \mathrm{a}$ \\
$\mathrm{S}_{2}$ & 94 & 97 & 83 & $91.3 \mathrm{a}$ \\
$\mathrm{S}_{4}$ & 54 & 80 & 55 & $63.0 \mathrm{~b}$ \\
$\mathrm{~S}_{8}$ & 55 & 60 & 55 & $56.7 \mathrm{c}$ \\
$\mathrm{S}_{16}$ & 49 & 56 & 47 & $50.6 \mathrm{~d}$ \\
mean & 68.8 & 77.4 & 66.8 & \\
\hline
\end{tabular}

This is in accord with previous research reports in wheat and triticale genotypes (Shalaby et al., 1993), phaseolus species (Bayuelo-Jimenez et al., 2002) and sugar beat, cabbage, amaranth and pak-choi (Jamil et al., 2006). Similar research results were reported in sorghum (Boursier and lauchli, 1992; Asfaw, 2011), wheat and triticale genotypes (Shalaby et al., 1993), barely (Cho and Kim, 1998) and prosopis alba (Meloni et al., 2004). On the other hand, the seedling dry biomass production was concurrently reduced as a result of increased salinity level in all cultivars. This is in agreement with previous research findings in wheat (Afzal et al., 2005) and sorghum (Asfaw, 2011).

Seedling growth was drastically decreased at higher salinity level, $8 \mathrm{dS} / \mathrm{m}$. However, the impact was remarkable on shoot compared to the root growth. This is in agreement with previous reports in lentil (Ashraf and Waheed, 1993), Maize (Çarkirlar and Çiçek, 2002), sorghum bicolour 1 (Asfaw, 2011). Salinity stress had no significant effect on seedling shoot and root dry weight in cultivar (V2).

In general, salt stress at $2 \mathrm{dS} / \mathrm{m}$ has not enhanced seed germination percentages, but it enhanced shoot and root growth in all cultivars. All cultivars were quite salt- sensitive at 4,8 and $16 \mathrm{dS} / \mathrm{m}$ with regard to shoot seedling dry weight and root seedling dry weight. Crop cultivar may germinate effectively under salt stress; nevertheless, its seedling growth may be salt affected (Azhar and McNeilly, 1987). In line with this, varieties $V_{2}$ was less salt- affected during germination (Geressu and Gezahagne, 2008). This implies that these cultivars are salt tolerant during germination than subsequent growth like seedling biomass production.

Table 3. The effect of salinity levels on seedling shoots dry weight (g) of Sorghum bicolor L. Moench cultivars

\begin{tabular}{ccccc}
\hline Treatments & $\mathrm{V}_{1}$ & $\mathrm{~V}_{2}$ & $\mathrm{~V}_{3}$ & Mean \\
\hline $\mathrm{S}_{0}$ & 0.09 & 0.06 & 0.08 & $0.08 \mathrm{~b}$ \\
$\mathrm{~S}_{2}$ & 0.16 & 0.25 & 0.18 & $0.20 \mathrm{a}$ \\
$\mathrm{S}_{4}$ & 0.06 & 0.10 & 0.07 & $0.08 \mathrm{~b}$ \\
$\mathrm{~S}_{8}$ & 0.03 & 0.05 & 0.02 & $0.03 \mathrm{c}$ \\
$\mathrm{S}_{16}$ & 0.01 & 0.02 & 0.01 & $0.01 \mathrm{~d}$ \\
Mean & 0.07 & 0.10 & 0.07 & \\
\hline
\end{tabular}

Table 4. The effect of salinity levels on seedling root dry weight (g) of Sorghum bicolor L. Moench cultivars

\begin{tabular}{ccccc}
\hline Treatments & $\mathrm{V}_{1}$ & $\mathrm{~V}_{2}$ & $\mathrm{~V}_{3}$ & Mean \\
\hline $\mathrm{S}_{0}$ & 0.05 & 0.07 & 0.05 & $0.06 \mathrm{a}$ \\
$\mathrm{S}_{2}$ & 0.03 & 0.05 & 0.04 & $0.04 \mathrm{~b}$ \\
$\mathrm{~S}_{4}$ & 0.01 & 0.04 & 0.04 & $0.03 \mathrm{c}$ \\
$\mathrm{S}_{8}$ & 0.01 & 0.02 & 0.02 & $0.02 \mathrm{~d}$ \\
$\mathrm{~S}_{16}$ & 0.01 & 0.02 & 0.01 & $0.01 \mathrm{e}$ \\
Mean & 0.02 & 0.04 & 0.03 & \\
\hline
\end{tabular}

On the other hand, crop genotype may be salt sensitive during both germination and seedling growth. This has already been reported in rice (Shannon et al., 1998) and sorghum (Asfaw, 2011). Similarly, in this research, cultivars $V_{1}$ and $\mathrm{V}_{3}$ found salt sensitive at higher salinity levels during germination and seedling biomass production. Thus this sorghum cultivar could not be directly cultivated even on slightly saline soils. On the other hand, cultivar $\left(\mathrm{V}_{2}\right)$ was found salt tolerant with respect to seedling biomass production. This cultivar also had the lowest germination rate (rapid emergence), the highest Final Germination Percentage (FGP). It salt tolerance capability might emanate from it faster germination which allowed the emerging seedlings to accumulate more biomass relative to the control (Bayuelo-Jimeenez et al., 2002; Asfaw, 2011). Thus due to the facilitated seedling root and shoot characteristics. Since this sorghum cultivar had rapid emergence, highest Final Germination Percentage (FGP), facilitated seedling growth, highest seedling biomass production; they could effectively establish it selves on moderately saline soils. 


\section{Conclusions}

The results revealed the presence of broad intra-specific variation among sorghum (Sorghum bicolorL. Moench) cultivars in response to salt stress during seed germination and seedling biomass production. The study proved that cultivar Wad Ahmed was the most salt tolerant of all sorghum cultivars studied. Thus this cultivar could be cultivated on slightly saline soils. For its rapid seedling emergence, highest final germination percentage, facilitated growth, highest biomass production. However, this could not be a guarantee for it to be salt tolerant in later growth stages. Therefore to recommend the cultivation of this sorghum cultivar in the field, it must be further profound field investigation at the whole plant growth stage.

\section{REFERENCES}

[1] Afzal, I., S. Maqsood, A. Basra, N. Ahmad and M. Farooq, 2005. Optimization of hormonal priming techniques for alleviation of salinity stress in wheat (Triticum aestivum L.). Caderno de Pesquisa S'r. Bio., Santa Cruz do Sul, 17(1): 95-109.

[2] Ahmed, S., 2009. Effect of soil salinity on the yield and yield components of Mungbean. Pak. J. Bot., 4(1):263-268.

[3] Asfaw, K. G. (2011). Effects of Salinity on Seedling Biomass Production and Relative Water Content of Twenty Sorghum (Sorghum biolor L. Moench) Accessions. Asian Journal of Agricultural Sciences, 3(3): 242-249

[4] Ashraf, M. and T. McNeilly, 1988. Variability in salttolerance of nine spring wheat cultivars. J. Agron. Crop. Sci., 160: $14-21$.

[5] Ashraf, M. and A. Waheed, 1993. Resposes of some local/exotic accessions of lentil (Lens culinaris Medic.) to salt stress. J. Agron. Crop Sci., 170:103-112.

[6] Ashraf,M., R.H. Athar, C.J.P. Harris and R.T. Kwon, 2008. Some prospective strategies for improving crop salt tolerance. Adv. Agron., 97: 45-110.

[7] Ashraf, M., 2009. Biotechnological approach of improving plant salt tolerance using antioxidants as markers. Biotech. Adv., 27: 84-93.

[8] Azhar, M.F. and T. McNeilly, 1987. Variability for salt tolerance in Sorghumn bicolor (L.) Moench. Under hydroponic conditions. J. Agron. Crop Sci., 159:269-277.

[9] Bayuelo-Jim'nez, J.S., R. Craig and J.P. Lynch, 2002.Salinity tolerance of phaseolus species during germination and early seedling growth. Crop Sci., 42:1584-1594.

[10] Boursier, P. and A. Läuchli, 1992. Growth Responses and mineral nutrient relations of salt-stressed sorghum. Crop Sci., 30(6): 1226-1233.

[11] Brady, N.C. and R. R.Weil, 2002. The Nature and Properties of Soils, 13th Edn., Prentice-Hall, Upper Saddle Rivers, New Jersey.
[12] Çarkirlar, H. and N. Çiçek, 2002. The effect of salinity on some hysiological parameters in two maize cultivars. Bulg. J. Plant Physiol., 28(1-2): 66-74.

[13] Cho, J.W. and C.S. Kim, 1998. Effect of $\mathrm{NaCl}$ concentration on photosynthesis and mineral content of barely seedlings under solution culture. Korean J. Crop Sci., 43(3): 152- 156.

[14] Duan, D., li, W., Ouyang, H. and An, P. (2007). Seed germination and seedling growth of Suaeda salsa under salt stress. Ann. Bot. Fennici, 44:161- 169

[15] EL-Khashab, A.A.M., A.A. Elaidy, A.F. EL-Sammak, M.I. Salama and M. Rienger, 1997. Paclobutrazol reduces some negative effects of salt stress in peach. J. Am. Soc. Hort. Sci., 122(1): 43-46.

[16] FAO, 2000. Land and Plant Nutrition Management Service: Global Network on Integrated Soil Management for Sustainable use of Salt-Affected Soils. FAO/AGL Rome. Retrieved from: http://www.fao.orglag/agl/agll/ spush/topic.htm, (Accessed on:November 30, 2000).

[17] Fricke, W., G. Akhiyarova, W. Wei., E. Alexanderssn, A. Miller, P.O. Kjellbom, A. Richardson, T. Wojciechowski, L. Schreiber, D. Veselov, G. Kudoyarova and V. Volkar, 2006. The short term growth responses to salt of the developing barley leaf. Journal Experimental Botany, 57(5): 1079-1095.

[18] Garthwaite, A.J., R. Von Bothmer and T.D. Colmer, 2005. Salt tolerance in wild Hordeum species is associated with restricted entry of $\mathrm{Na}+$ and $\mathrm{Cl}$ - into the shoots. Journal of Experimental Botany, 56: 2365-2378.

[19] Gebre, H. and K. Georgis, 1988. Sustaining crop production in the semi-arid areas of Ethiopia. Eth. J. Agric. Sci., 10(1-2): 99-107.

[20] Geressu, K. and M. Gezahagne, 2008. Response of some lowland growing sorghum (Sorghum bicolor L. Moench) accessions to salt stress during germination and seedling growth. Afr. J. Agric. Res., 3(1): 044-048.

[21] Gomez K. A. and Gomez A. A. 1984. Statistical for Agricul tural Research. John. Wiley and Sons. New York

[22] Gupta, R. and P.S. Minhas, 1993. Managing Salt Affected Waters for Crop Production. In: Singh, S.D. (Ed.), Arid Land Irrigation and Ecological Management. Scientific Publishers, Jodhpur (India), New Delhi,pp: 159-198.

[23] Haider, G., G. Desta, T. Hordofa and E. Bekele, 1988. Soil Salinity and Ground Water Survey of Melka Werer Research Center Farm. Institute of Agriculture Research, Melka Werer Research Center, Ethiopia, pp: 42.

[24] Jaleel, C.A., B. Sankar, R. Sridharan and R. Panneerselvam, 2008. Soil salinity alters growth, chlorophyll content and secondary metabolite accumulation in Catharanthus roseus. Turk. J. Biol.,32: 79-83.

[25] Jamil, M., D.B. Lee, K.Y. Jung, M. Ashraf, S.C. Lee and S.E. Rha, 2006. Effect of salt $(\mathrm{NaCl})$ stress on germination and early seedling growth of four Vegetable species. J. Central Eur. Agric., 7(2): 273-282.

[26] Kanai, M., K. Higuchi, T. Hagihara, T. Konishi, T. Ishii, N. Fujita, Y. Nakamura, Y. Maeda, M. Yoshiba and T. Tadano, 2007. The common reed produces starch granules at the shoot base in response to salt stress. New Phytologist, 176: 572-580 
[27] Katerji, N., J.W. van Hoorn, A. Hamdy, F. Karam and M. Mastrorilli, 1994. Effect of salinity on emergence and on water stress and early seedling growth of sunflower and maize. Agric. Water Manage., 26: 81-91.

[28] Keshavarzi, M. H. B. (2011). Effect of Salt Stress on Germination and Early Seedling Growth of Savory (Satureja hortensis). Australian Journal of Basic and Applied Sciences, 5(12): 3274-3279

[29] Lee, S.Y. and D. Senadhira, 1998. Salinity tolerance of progenies between Korean cultivars and IRR's New Plant Type lines in rice. Korena J. Crop Sci., 43(4): 234-238.

[30] Maas, V.E., 1986. Salt tolerance of plants. Appl. Agric. Res., 1: $12-26$.

[31] Mamo, T., C. Richter and B. Heiligatag, 1996. Response of some varieties of durum wheat and tef to salt stress. Afr. Crop Sci. J., 4(4): 423-432.

[32] Mahmood, A., T. Latif and A.M. Khan, 2009. Effect of salinity on growth, yield and yield components in Basmati rice germplasm. Pak. J. Bot., 41(6): 3035-3045.

[33] Marambe, B. and T. Ando, 1995. Physiological basis of salinity tolerance of sorghum seeds during germination. J. Agron. Crop. Sci., 174: 291-296.

[34] Marler, T.E. and M.V. Mickelbart, 1993. Growth and chlorophyll fluorescence of Spondias purpurea L. as influenced by salinity. Trop. Agri. (Trinidad), 70(3): 245-247.

[35] Meloni, D.A., M.R. Gulotta, C.A. Martinez and M.A. Oliva, 2004. The effect of salt stress on growth, nitrate reduction and proline and glycinebetaine accumulation in prosopis alba.
Braz. J. Plant Physiol., 16(1): 39-46.

[36] Munns, R., James, R.A. and A. Lauchli, 2006. Approaches to increasing the salt tolerance of wheat and other cereals. J. Exp. Bot., 57: 1025.

[37] Neumann, P., 1997. Salinity resistance and plant growth revisited. Plant Cell and Environment, 20: 1193-1198

[38] Noreen, S. and M. Ashraf, 2008. Alleviation of adverse effects of salt stress on sunflower (Helianthus annuus L.) by exogenous application of salicylic acid: Growth and photosynthesis. Pak. J. Bot., 40(4): 1657-1663.

[39] Shalaby, E.E., E. Epstein and O.C. Qualset, 1993. Variation in salt tolerance among some wheat and triticale genotypes. J. Agron. Crop. Sci., 171:298-304.

[40] Shannon, M.C., J.D. Rhoads, J.H. Draper, S.C. Scardoli and M.D. Spyres, 1998. Assessment of salt tolerance in rice cultivars in response to salinity problems in california. Crop Sci., 38(2): 394-398.

[41] Ungar, IA., 1995. Seed germination and seed-bank ecology of halophytes Marcel. Dekker, New York, pp:599-627.

[42] Verma, S.P.O. and R.B.R. Yadava, 1986. Salt tolerance of some oats (Avena sativa L.) varieties at germination and seedling stage. J. Agron. Crop Sc., 156: 123-127.

[43] Werner, J.E. and R.R. Finkelstein, 1995. Arabidopsis mutants with reduced response to $\mathrm{NaCl}$ and osmotic stress. Physiologia Plantarum, 93(4): 659-666. 